answers]. Moscov: Vydavnytstvo VLADOS - PRES Publ., 267 p. [in Ukrainian].

6. Savchenko, O. Ya. (2012). Navchalne seredovyshche yak chynnyk stymuliuvannia doslidnytskoi diialnosti molodshykh shkoliariv [Educational surrounding as a factor in stimulating the research activities of junior pupils]. Scientific notes of the Junior Academy of Sciences of Ukraine, vol. 1, pp. 41 - 49. [in Ukrainian].

7. Skvortsova, S. \& Onopriienko, O. (2015). Urokdoslidzhennia z matematyky u pochatkovii shkoli [Research lesson on math in elementary school] Elementary School, vol. 12, pp. 13-17. [in Ukrainian].

Стаття надійшла до редакції 09.03.2018

УДК 378.016:376

DOI:

Юрій Долинний, кандидат педагогічних наук, дочент, докторант кафедри педагогіки і методики технологічної освіти Глухівського національного педагогічного університету імені О. Довженка

\title{
СТАТИСТИЧНА ОБРОБКА ПОКАЗНИКІВ МОТИВАЦЙНОГО ТА КОГНІТИВНОГО КРИТЕРІЮ ГОТОВНОСТІ МАЙБУТНІХ БАКАЛАВРІВ З ФІЗИЧНОГО ВИХОВАННЯ І СПОРТУ ДО РЕАБІЛІТАЦІЙНОЇ РОБОТИ З ДІТЬМИ 3 ОБМЕЖЕНИМИ ФІЗИЧНИМИ МОЖЛИВОСТЯМИ
}

У статті розглянуто показники мотиваиійного та когнітивного критерію готовності майбутніх бакалаврів з фізичного виховання і спорту до реабілітаиійної роботи з дітьми з обмеженими фізичними моэливостями.

При виріменні завдань дослідження реалізачії практичної складової системи професійної підготовки фахівиів з фізичного виховання $і$ спорту до реабілітаційної роботи з дітьми з обмеэсеними фізичними можливостями була застосована математична статистика та аналізувались наступні показники статистичноі обробки: середнс арифметичне значення величини ( $\overline{\mathrm{X}})$; помилка обчислення середньої арифметичної величини $(s) ;$ середнє квадратичне відхилення, якехарактеризує мінливість ознаки $(\sigma)$ вірогідність різнииі середніх величин (t). Оиінка вірогідності різниці статистичних показників (t) проводилась за критерієм Стьюдента. Для перевірки достовірності покращееня результатів контрольних тестів значення $F$ розрахункового порівнювались 3

критичними $F_{\alpha, \gamma 1, \gamma 2}$ із таблиці теоретичного розподілення Фімера для $\alpha=0,05$.

Ключові слова: дослідження, експеримент, математична статистика, арифметичне значення, фахівиі, фізичне виховання, реабілітація, професійна підготовка.

Рис. 4. Табл. 4. Літ. 10.

Yuriy Dolynnyi, Ph.D. (Pedagogy), Associate Professor, Doctoral Student of the Pedagogics and Method of Technological Science Department Hlukhiv Oleksander Dovzhenko National Pedagogical University

\section{STATISTICALTREATMENT OFINDEXES OF MOTIVATIONALANDCOGNITIVE CRITERION OFREADINESS OF FUTURE BACHELORSOFPHYSICALEDUCATIONAND SPORTTO REHABILITATIONWORKWITHCHILDRENWITHLIMITPHYSICALPOSSIBILITIES}

The article presents the indexes of motivational and cognitive criterion of readiness of future bachelors of physical education and sport to rehabilitation work with children with limit physical possibilities.

At the decision of tasks of research to realization of the practical component system of professional preparation of specialists on physical education and sport to rehabilitation work with children with limit physical possibilities were applied the mathematical statistics and such parameters were analyzed: mean arithmetic value of size $(\overline{\mathrm{X}})$ error of calculation of arithmetic average (s); standard deviation that characterizes the changeability of sign $(\sigma)$ authenticity of difference of averages $(t)$. The estimation of authenticity of difference of statistical indexes $(t)$ was conducted on the criterion of students. For verification of authenticity of improvement of results of control tests of value of $F$ calculation compared to critical from a theoretical allocation of Fisher map for $=0,05$.

Keywords: a research, an experiment, mathematical statistics, arithmetic value, the specialists, physical education, rehabilitation, professional preparation.

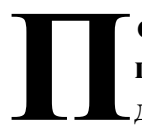

остановка науково-практичної проблеми. Процес становлення нашої держави, демократичний розвиток суспільства, соціальна політика України вимагає переходу до нового типу гуманістичноінноваційної фізкультурної освіти, яка
(C)

Ю. Долинний, 2018 


\section{СТАТИСТИЧНА ОБРОБКА ПОКАЗНИКІВ МОТИВАЦИЙНОГО ТА КОГНІТИВНОГО КРИТЕРІЮ ГОТОВНОСТІ МАЙБУТНІХ БАКАЛАВРІВ 3 ФІЗИЧНОГО ВИХОВАННЯ І СПОРТУ ДО

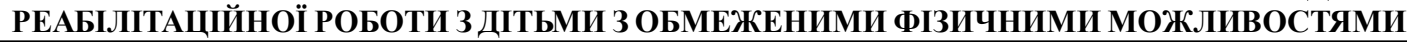

здійснюється на основі впровадження нового змісту, форм, методів навчання, підвищення якості професійної підготовки, розвитку професійно значущих якостей майбутнього фахівця 3 фізичного виховання та спорту, що відповідають вимогам сучасної реабілітаційної роботи з дітьми $[4 ; 6]$.

Актуальність і новизна дослідження. Актуальною проблемою сучасної педагогічної теорії і практики є процеси професійної підготовки майбутніх фахівців 3 фізичного виховання і спорту до реабілітаційної роботи 3 дітьми з обмеженими фізичними можливостями у вищій школі. Підвищена увага до цього питання великої кількості педагогів, психологів, соціологів зумовлена тим, що діти з обмеженими фізичними можливостями в сучасному демократичному суспільстві не мають права залишатися на узбіччі соціально-культурних процесів, системи людських взаємин і цінностей. Ці діти мають такі ж права, як і здорові: їм необхідно повноцінно навчатися, отримувати загальну освіту та в майбутньому приносити користь суспільству та державі $[5 ; 7]$.

Зв'язок теми статті 3 важливими науковопрактичними завданнями. Тема дослідження включена до плану науково-дослідної роботи кафедри педагогіки і методики технологічної освіти Глухівського національного педагогічного університету імені Олександра Довженка.

Аналіз останніх публікацій за темою дослідження. Реалізацію принципу неперервності професійної підготовки майбутніх фахівців фізичного виховання та спорту досліджували І.М. Башкін, Н.О. Бєлікова, Р.Ю. Гайволя, Л.О. Демінська, С.У. Гончаренко, І.А. Зязюн, С.О. Сисоєва, В.О. Кукса, Л.П. Сущенко й інші [1- $4 ; 8 ; 10]$.

Проблему дітей з обмеженими фізичними можливостями та корекційну роботу з такими дітьми розглядали І.Д. Бех, В.І. Бондар, Ю.О. Долинний, В.В. Засенко, Д.В. Лубовський, О.В. Гузій, О.С. Куц, Є.М. Мастюкова, Г.М. Мерсіянова, В.М. Синьов, Є.Ф. Соботович, В.М. Оржеховська, Л.В. Фомічова, О.П. Хохліна, М.Д. Ярмаченко [5 - 7].

Особливості реабілітаційної роботи засобами фізичної реабілітації з людьми, що мають обмеження в розвитку, досліджували І.М. Башкін, Т.В. Бойчук, О.М. Вацеба, А.С. Вовканич, Т.В. Д'яченко, Ю.О. Ляной, О.К. Марченко, B.М. Мухін, С.Н. Попов [9].

Мета статті. Перевірити достовірність покращення показників мотиваційного та когнітивного критерію готовності майбутніх бакалаврів 3 фізичного виховання і спорту до реабілітаційної роботи 3 дітьми 3 обмеженими фізичними можливостями за критичними $F_{\alpha, \gamma 1, \gamma 2}$ із таблиці теоретичногорозподілення Фішерадля $\alpha=0,05$.

Викладення основного матеріалу. Реалізація практичної складової системи професійної підготовки фахівців 3 фізичного виховання i спорту до реабілітаційної роботи 3 дітьми 3 обмеженими фізичними можливостями проводилась у 12 закладах вищої освіти України.

Навчальний процес в експериментальних групах організовували 3 упровадженням “Програми підготовки фахівців 3 фізичного виховання і спорту до реабілітаційної роботи 3 дітьми з обмеженими фізичними можливостями". Відмінності в досліджуваних групах залежали від умов проведення, представлених у загальній програмі підготовки фахівців даного напрямку підготовки. Заняття 3 експериментальної "Програми підготовки фахівців 3 фізичного виховання і спорту до реабілітаційної роботи 3 дітьми з обмеженими фізичними можливостями" в досліджуваних групах проводили за робочим навчальним планом експериментальної програми у кількості 24 годин на тиждень.

Студенти контрольних груп навчалися згідно iз загальноосвітньою програмою підготовки фахівців з фізичної реабілітації закладу вищої освіти. Експеримент було побудовано на загальноприйнятих принципах і методах навчання. Для визначення динаміки освоєння експериментальної та загальної навчальної програми підготовки майбутніх бакалаврів 3 фізичної реабілітації з 2 по 4 курс (2014 - 15 н.р., 2015 - 16 н.p., 2016 - 17 н.р.) був взятий $з$ робочого навчального плану середній кількісний показник навчальних годин за 3 роки навчання у кількості 2000 годин із розрахунку 22,5 години на тиждень 3 урахуванням 89 тижнів навчання за 3 роки. Визначення динаміки освоєння експериментальної та загальної навчальної програми підготовки майбутніх бакалаврів під час експерименту оцінювалось за 4 контрольними точками за весь період експериментальної роботи (з 2014 - 2017 рік). Перша контрольна точка від 0 до 500 навчальних годин; друга контрольна точка від 500 до 1000 навчальних годин; третя від 1000 до 1500 навчальних годин; четверта від 1500 до 2000 навчальних годин. Аналіз динаміки показників впливу освоєння експериментальної та загальної навчальної програми на рівень навченості бакалаврів проводився через кожних 500 навчальних занять за результатами запитань (\%) відношення мотиваційного, когнітивного, готовності майбутніх фахівців 3 фізичного виховання і спорту до реабілітаційної роботи 3 дітьми з обмеженими фізичними можливостями. 


\section{СТАТИСТИЧНА ОБРОБКА ПОКАЗНИКІВ МОТИВАЩЙНОГО ТА КОГНІТИВНОГО КРИТЕРІЮ \\ ГОТОВНОСТІ МАЙБУТНІХ БАКАЛАВРІВ 3 ФІЗИЧНОГО ВИХОВАННЯ І СПОРТУ ДО РЕАБІЛІТАЦІЙНОЇ РОБОТИ З ДІТЬМИ З ОБМЕЖЕНИМИ ФІЗИЧНИМИ МОЖЛИВОСТЯМИ}

Таблиця 1.

Показники приросту мотиваційного критерію готовності спрямованого на виявлення учбово-пізнавальної мотивації майбутніх бакалаврів 3 фізичної реабілітації, вчителів 3 фізичної культури під час навчання

\begin{tabular}{|c|c|c|c|c|c|c|}
\hline \multirow[t]{2}{*}{ Групи } & \multirow[t]{2}{*}{ Рівень } & \multirow{2}{*}{$\begin{array}{c}\text { Статистичні } \\
\text { показники }\end{array}$} & \multicolumn{4}{|c|}{ Навчальні заняття } \\
\hline & & & 500 & 1000 & 1500 & 2000 \\
\hline \multirow[t]{3}{*}{ КГ } & \multirow[t]{3}{*}{ Високий } & $\overline{\mathrm{X}}$ & 0,5 & 0,5 & 0,25 & 0,25 \\
\hline & & $\sigma$ & 0,58 & 0,58 & 0,5 & 0,5 \\
\hline & & $\mathrm{t}$ & 1,$73 ; \mathrm{P}>0,05$ & 1,$73 ; \mathrm{P}>0,05$ & $1 ; \mathrm{P}>0,05$ & $1 ; \mathrm{P}>0,05$ \\
\hline \multirow[t]{3}{*}{$\mathrm{E} \Gamma$} & \multirow[t]{3}{*}{ Високий } & $\bar{X}$ & 2 & 1,25 & 1,75 & 1,75 \\
\hline & & $\sigma$ & 0,82 & 0,5 & 0,5 & 0,5 \\
\hline & & $\mathrm{t}$ & 4,$9 ; \mathrm{P}<0,05$ & $5 ; \mathrm{P}<0,05$ & $7 ; \mathrm{P}<0,05$ & $7 ; \mathrm{P}<0,05$ \\
\hline \multirow[t]{3}{*}{ КГ } & \multirow[t]{3}{*}{ Середній } & $\bar{X}$ & 1,75 & 1,5 & 1,5 & 0,75 \\
\hline & & $\sigma$ & 0,96 & 0,58 & 0,58 & 0,5 \\
\hline & & $\mathrm{t}$ & 3,$65 ; \mathrm{P}<0,05$ & 5,$2 ; \mathrm{P}<0,05$ & 5,$2 ; \mathrm{P}>0,05$ & $3 ; \mathrm{P}>0,05$ \\
\hline \multirow[t]{3}{*}{$\mathrm{E} \Gamma$} & \multirow[t]{3}{*}{ Середній } & $\overline{\mathrm{X}}$ & 1,75 & 1,5 & 1,25 & 0,5 \\
\hline & & $\sigma$ & 0,5 & 0,58 & 0,5 & 0,58 \\
\hline & & $\mathrm{t}$ & $7 ; \mathrm{P}<0,05$ & 5,$2 ; \mathrm{P}<0,05$ & $5 ; \mathrm{P}<0,05$ & 1,$7 ; \mathrm{P}>0,05$ \\
\hline \multirow[t]{3}{*}{ КГ } & \multirow[t]{3}{*}{ Достатній } & $\bar{X}$ & 2,5 & 1,25 & 0,75 & 1 \\
\hline & & $\sigma$ & 0,58 & 0,5 & 0,96 & 0,82 \\
\hline & & $\mathrm{t}$ & 8,$66 ; \mathrm{P}<0,05$ & $5 ; \mathrm{P}<0,05$ & 1,$56 ; \mathrm{P}>0,05$ & 2,$44 ; \mathrm{P}<0,05$ \\
\hline \multirow[t]{3}{*}{$\mathrm{E} \Gamma$} & \multirow[t]{3}{*}{ Достатній } & $\bar{X}$ & 2,5 & 0,75 & 1 & 0,75 \\
\hline & & $\sigma$ & 0,58 & 0,5 & 0,82 & 0,5 \\
\hline & & $\mathrm{t}$ & 8,$6 ; \mathrm{P}<0,05$ & $3 ; \mathrm{P}<0,05$ & 2,$4 ; \mathrm{P}>0,05$ & $3 ; \mathrm{P}>0,05$ \\
\hline \multirow[t]{3}{*}{ КГ } & \multirow[t]{3}{*}{ Низький } & $\bar{X}$ & 3,5 & 3 & 1,5 & 0,5 \\
\hline & & $\sigma$ & 1,73 & 1,15 & 1,29 & 0,58 \\
\hline & & $\mathrm{t}$ & $4 ; \mathrm{P}<0,05$ & 5,$2 ; \mathrm{P}<0,05$ & 2,$3 ; \mathrm{P}>0,05$ & 1,$7 ; \mathrm{P}>0,05$ \\
\hline \multirow[t]{3}{*}{$\mathrm{E} \Gamma$} & \multirow[t]{3}{*}{ Низький } & $\bar{X}$ & 1 & 1,25 & 0,25 & 1 \\
\hline & & $\sigma$ & 0,82 & 0,5 & 0,5 & 0,82 \\
\hline & & $\mathrm{t}$ & 2,$4 ; \mathrm{P}<0,05$ & $5 ; \mathrm{P}<0,05$ & $1 ; \mathrm{P}>0,05$ & 2,$4 ; \mathrm{P}<0,05$ \\
\hline \multicolumn{7}{|c|}{$t_{(0,05 ; 3)}=2,35$} \\
\hline
\end{tabular}

Для обробки результатів отриманих даних застосовувались методи математичної статистики (Б.А. Суслаков (1982), В.С. Іванов (1990), Ю.М. Тюрін (1998), Н.Ш. Кремер (2000) та інші), які забезпечують кількісний і якісний аналіз.

Дані оброблялись засобами статистичного пакету комп'ютерної програми Microsoft Excel 8.0 for Windows. Оцінка статистичних гіпотез виходила із 5\% рівня значимості, який забезпечує необхідну точність у педагогічних дослідженнях [2].

Для об’єктивного проведення експерименту на кожний критерій готовності майбутніх фахівців 3 фізичної реабілітації; вчителів з фізичної культури були розроблені по дві анкети запитань:

- анкета № 1 дослідження мотиваційного критерію спрямована на виявлення учбовопізнавальної мотивації студентів (майбутніх фахівців з фізичної реабілітації; вчителів з фізичної культури) під час навчання у вищих навчальних закладах України;

- анкета № 2 дослідження мотиваційного критерію спрямована на виявлення діяльнісної мотивації студентів (майбутніх фахівців з фізичної 
СТАТИСТИЧНА ОБРОБКА ПОКАЗНИКІВ МОТИВАЦІЙНОГО ТА КОГНІТИВНОГО КРИТЕРІЮ

ГОТОВНОСТІ МАЙБУТНІХ БАКАЛАВРІВ 3 ФІЗИЧНОГО ВИХОВАННЯ І СПОРТУ ДО

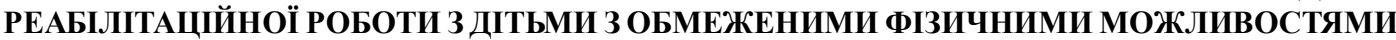

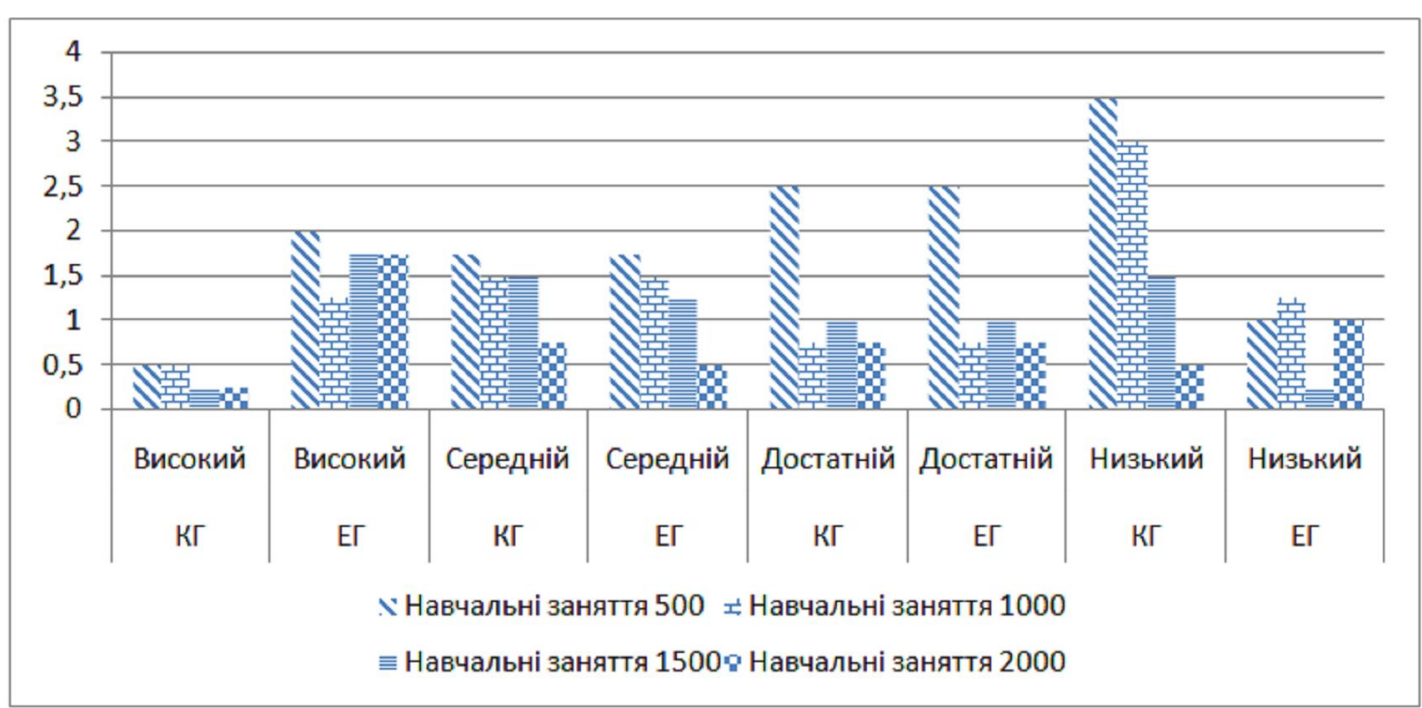

Рис. 1. Гістограма приросту показників мотиваційного критерію готовності спрямованого на виявлення учбово-пізнавальної мотивації майбутніх бакалаврів з фізичної реабілітації, вчителів 3 фізичної культури під час навчання

Таблиця 2.

Показники приросту мотиваційного критерію готовності спрямованого на виявлення діяльнісної мотивації майбутніх бакалаврів з фізичної реабілітації, вчителів 3 фізичної культури під час навчання

\begin{tabular}{|c|c|c|c|c|c|c|}
\hline \multirow[t]{2}{*}{ Групи } & \multirow[t]{2}{*}{ Рівень } & \multirow{2}{*}{$\begin{array}{c}\text { Статистичні } \\
\text { показники }\end{array}$} & \multicolumn{4}{|c|}{ Навчальні заняття } \\
\hline & & & 500 & 1000 & 1500 & 2000 \\
\hline \multirow[t]{3}{*}{ КГ } & \multirow[t]{3}{*}{ Високий } & $\bar{X}$ & 1 & 0,5 & 1 & 0,5 \\
\hline & & $\sigma$ & 0,8 & 0,59 & 0,59 & 0,6 \\
\hline & & $\mathrm{t}$ & 2,$44 ; \mathrm{P}<0,05$ & 1,$73 ; \mathrm{P}>0,05$ & 1,$7 ; \mathrm{P}>0,05$ & $2 ; \mathrm{P}>0,05$ \\
\hline \multirow[t]{3}{*}{$\mathrm{E} \Gamma$} & \multirow[t]{3}{*}{ Високий } & $\overline{\mathrm{X}}$ & 2 & 1,25 & 0,5 & 1,5 \\
\hline & & $\sigma$ & 0,8 & 0,5 & 1 & 1,3 \\
\hline & & $\mathrm{t}$ & 4,$9 ; \mathrm{P}<0,05$ & $5 ; \mathrm{P}<0,05$ & $2 ; \mathrm{P}>0,05$ & $2 ; \mathrm{P}>0,05$ \\
\hline \multirow[t]{3}{*}{ КГ } & \multirow[t]{3}{*}{ Середній } & $\bar{X}$ & 2,5 & 1,3 & 1,25 & 1 \\
\hline & & $\sigma$ & 1,29 & 0,5 & 0,5 & 0,8 \\
\hline & & $\mathrm{t}$ & 3,$8 ; \mathrm{P}<0,05$ & $5 ; \mathrm{P}<0,05$ & $5 ; \mathrm{P}<0,05$ & 2,$4 ; \mathrm{P}<0,05$ \\
\hline \multirow[t]{3}{*}{$\mathrm{E} \Gamma$} & \multirow[t]{3}{*}{ Середній } & $\bar{X}$ & 1,5 & 1,25 & 0,75 & 0 \\
\hline & & $\sigma$ & 1,3 & 0,5 & 0,5 & 0,82 \\
\hline & & $\mathrm{t}$ & 2,$3 ; \mathrm{P}>0,05$ & $5 ; \mathrm{P}<0,05$ & $3 ; \mathrm{P}<0,05$ & $0 ; \mathrm{P}>0,05$ \\
\hline \multirow[t]{3}{*}{ КГ } & \multirow[t]{3}{*}{ Достатній } & $\bar{X}$ & 1,8 & 1 & 1 & 1 \\
\hline & & $\sigma$ & 1,5 & 0,8 & 0,8 & 1,4 \\
\hline & & $\mathrm{t}$ & 2,$3 ; \mathrm{P}>0,05$ & 2,$4 ; \mathrm{P}<0,05$ & $2 ; \mathrm{P}>0,05$ & 1,$44 ; \mathrm{P}>0,05$ \\
\hline \multirow[t]{3}{*}{$\mathrm{E} \Gamma$} & \multirow[t]{3}{*}{ Достатній } & $\overline{\mathrm{X}}$ & 2 & 0 & 1 & 1,3 \\
\hline & & $\sigma$ & 0,5 & 1,4 & 0,82 & 0,5 \\
\hline & & $\mathrm{t}$ & $7 ; \mathrm{P}<0,05$ & $0 ; \mathrm{P}>0,05$ & 2,$4 ; \mathrm{P}<0,05$ & $5 ; \mathrm{P}<0,05$ \\
\hline \multirow[t]{3}{*}{ КГ } & \multirow[t]{3}{*}{ Низький } & $\bar{X}$ & 2 & 1 & 0,8 & 1,75 \\
\hline & & $\sigma$ & 1,7 & 0,5 & 1 & 0,25 \\
\hline & & $\mathrm{t}$ & 2,$0 ; \mathrm{P}>0,05$ & $5 ; \mathrm{P}<0,05$ & $2 ; \mathrm{P}>0,05$ & 2,$7 ; \mathrm{P}<0,05$ \\
\hline \multirow[t]{3}{*}{$\mathrm{E} \Gamma$} & \multirow[t]{3}{*}{ Низький } & $\bar{X}$ & 0,5 & 1 & 0,5 & 1 \\
\hline & & $\sigma$ & 0,58 & 0,5 & 0,6 & 0,8 \\
\hline & & $\mathrm{t}$ & 1,$73 ; \mathrm{P}>0,05$ & $3 ; \mathrm{P}<0,05$ & $2 ; \mathrm{P}>0,05$ & $2 ; \mathrm{P}>0,05$ \\
\hline \multicolumn{7}{|c|}{$t_{(0,05 ; 3)}=2,35$} \\
\hline
\end{tabular}




\section{СТАТИСТИЧНА ОБРОБКА ПОКАЗНИКІВ МОТИВАЦІЙНОГО ТА КОГНІТИВНОГО КРИТЕРІЮ ГОТОВНОСТІ МАЙБУТНІХ БАКАЛАВРІВ 3 ФІЗИЧНОГО ВИХОВАННЯ І СПОРТУ ДО РЕАБІЛІТАЦІЙНОЇ РОБОТИ $З$ ДІТЬМИ $З$ ОБМЕЖЕНИМИ ФІЗИЧНИМИ МОЖЛИВОСТЯМИ}

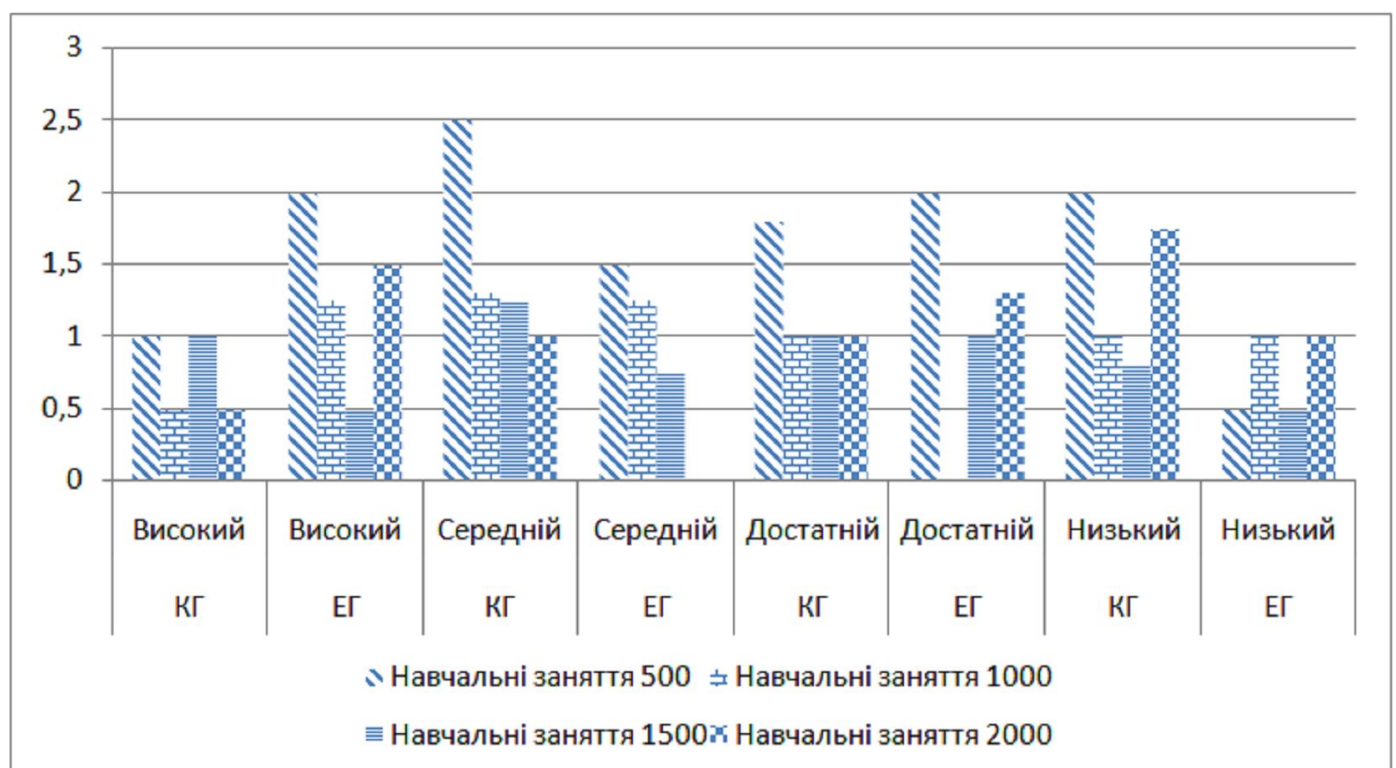

Рис. 2. Гістограма приросту показників мотиваційного критерію готовності спрямованого на виявлення діяльнісної мотивації майбутніх бакалаврів 3 фізичної реабілітації, вчителів 3 фізичної культури під час навчання

реабілітації; вчителів з фізичної культури) під час навчання у вищих навчальних закладах України;

- анкета № 3, 4 дослідження спрямована на виявлення когнітивного критерію у студентів (майбутніх фахівців з фізичної реабілітації; вчителів з фізичної культури).

У результаті проведених досліджень нами було виявлено найбільш впливову навчальну програму. За показниками учбової підготовленості студенти на початку педагогічного експерименту мало відрізнялись один від одного $(\mathrm{P}<0,05)$. Навчальні заняття проводилися паралельно в дослідних групах за експериментальною програмою підготовки фахівців 3 фізичного виховання i спорту до реабілітаційної роботи так і в контрольних групах відповідно до розкладу звичайних робочих навчальних планів того чи іншого закладу вищої освіти у середньої кількості 22,5 годин на тиждень.

Результати динаміки дослідження приведених в таблицях $1-4$ відображають характеристику показників мотиваційного та когнітивного критеріїв готовності майбутнього бакалавра 3 фізичної реабілітації у контрольній та експериментальній групі на анкетування.

Аналіз результатів анкети № 1 дослідження мотиваційного критерію готовності спрямованого на виявлення учбово-пізнавальної мотивації майбутніх фахівців з фізичної реабілітації, вчителів 3 фізичної культури під час навчання з 2014 по 2017 навчальний рік у вищих навчальних закладах України (таблиця 1 та рис. 1) дав змогу виявити найбільший приріст середніх арифметичних різниць високого, середнього, достатнього та низького рівня оцінювання контрольних i експериментальних груп:

1. Після першого контрольного тестування (500 занять):

- у 2,5 разів в КГ та ЕГ найбільший приріст середніх арифметичних різниць на достатньому рівні;

- у 3,5 разів у КГ найбільший приріст середніх арифметичних різниць на високому рівні;

- в 2 рази у ЕГ найбільший приріст середніх арифметичних різниць на високому рівні.

2. Після другого контрольного тестування (1000 занять):

- у 1,5 разів в КГ та ЕГ найбільший приріст середніх арифметичних різниць на середньому рівні;

- у 3,0 разів у КГ найбільший приріст середніх арифметичних різниць на низькому рівні.

3. Після третього контрольного тестування (1500 занять):

- у 1,75 разів в ЕГ найбільший приріст середніх арифметичних різниць на високому рівні;

- у 1,5 разів в КГ найбільший приріст середніх арифметичних різниць на низькому рівні.

4. Після четвертого контрольного тестування (2000 занять):

- у 1,75 разів в ЕГ найбільший приріст середніх арифметичних різниць на високому рівні;

На основі отриманих показників приросту мотиваційного критерію готовності можемо розробити гістограму приросту показників мотиваційного критерію спрямованого на 


\section{СТАТИСТИЧНА ОБРОБКА ПОКАЗНИКІВ МОТИВАЦЙНОГО ТА КОГНІТИВНОГО КРИТЕРІЮ \\ ГОТОВНОСТІ МАЙБУТНІХ БАКАЛАВРІВ 3 ФІЗИЧНОГО ВИХОВАННЯ І СПОРТУ ДО \\ РЕАБІЛІТАЦІЙНОЇ РОБОТИ 3 ДІТЬМИ $З$ ОБМЕЖЕНИМИ ФІЗИЧНИМИ МОЖЛИВОСТЯМИ}

Таблиця 3

Показники приросту когнітивного критерію готовності майбутніх бакалаврів 3 фізичної реабілітації, вчителів з фізичної культури під час навчання

\begin{tabular}{|c|c|c|c|c|c|c|}
\hline \multirow[t]{2}{*}{ Групи } & \multirow[t]{2}{*}{ Рівень } & \multirow{2}{*}{$\begin{array}{c}\text { Статистичні } \\
\text { показники }\end{array}$} & \multicolumn{4}{|c|}{ Навчальні заняття } \\
\hline & & & 500 & 1000 & 1500 & 2000 \\
\hline \multirow[t]{3}{*}{ КГ } & \multirow[t]{3}{*}{ Високий } & $\overline{\mathrm{X}}$ & 2,2 & 1 & 0,4 & 0,4 \\
\hline & & $\sigma$ & 0,84 & 0,71 & 1,14 & 0,89 \\
\hline & & $\mathrm{t}$ & 5,$8 ; \mathrm{P}<0,05$ & 3,$2 ; \mathrm{P}<0,05$ & 0,$8 ; \mathrm{P}>0,05$ & $1 ; \mathrm{P}>0,05$ \\
\hline \multirow[t]{3}{*}{$\mathrm{E} \Gamma$} & \multirow[t]{3}{*}{ Високий } & $\overline{\mathrm{X}}$ & 2,8 & 2 & 0,8 & 1,8 \\
\hline & & $\sigma$ & 1,3 & 0,71 & 0,84 & 1,3 \\
\hline & & $\mathrm{t}$ & 4,$8 ; \mathrm{P}<0,05$ & 6,$3 ; \mathrm{P}<0,05$ & 2,$1 ; \mathrm{P}<0,05$ & 3,$08 ; \mathrm{P}<0,05$ \\
\hline \multirow[t]{3}{*}{ КГ } & \multirow[t]{3}{*}{ Середній } & $\overline{\mathrm{X}}$ & 2,8 & 2,2 & 1,4 & 1 \\
\hline & & $\sigma$ & 0,8 & 1,4 & 0,5 & 0,7 \\
\hline & & $\mathrm{t}$ & 7,$4 ; \mathrm{P}<0,05$ & $11 ; \mathrm{P}<0,05$ & 5,$7 ; \mathrm{P}<0,05$ & 3,$1 ; \mathrm{P}<0,05$ \\
\hline \multirow[t]{3}{*}{$\mathrm{E} \Gamma$} & \multirow[t]{3}{*}{ Середній } & $\bar{X}$ & 2,2 & 2,2 & 2 & 0,8 \\
\hline & & $\sigma$ & 0,8 & 1,3 & 1 & 2,0 \\
\hline & & $\mathrm{t}$ & 5,$8 ; \mathrm{P}<0,05$ & 3,$7 ; \mathrm{P}<0,05$ & 4,$4 ; \mathrm{P}<0,05$ & 0,$8 ; \mathrm{P}>0,05$ \\
\hline \multirow[t]{3}{*}{ КГ } & \multirow[t]{3}{*}{ Достатній } & $\bar{X}$ & 2,2 & 1 & 2 & 0 \\
\hline & & $\sigma$ & 0,8 & 1,4 & 1 & 1 \\
\hline & & $\mathrm{t}$ & 5,$8 ; \mathrm{P}<0,05$ & 1,$6 ; \mathrm{P}>0,05$ & 4,$5 ; \mathrm{P}<0,05$ & $0 ; \mathrm{P}>0,05$ \\
\hline \multirow[t]{3}{*}{$\mathrm{E} \Gamma$} & \multirow[t]{3}{*}{ Достатній } & $\overline{\mathrm{X}}$ & 3,4 & 2,2 & 1,4 & 0,8 \\
\hline & & $\sigma$ & 0,9 & 0,4 & 0,5 & 0,7 \\
\hline & & $\mathrm{t}$ & 8,$5 ; \mathrm{P}<0,05$ & $11 ; \mathrm{P}<0,05$ & 5,$7 ; \mathrm{P}<0,05$ & 3,$1 ; \mathrm{P}<0,05$ \\
\hline \multirow[t]{3}{*}{ КГ } & \multirow[t]{3}{*}{ Низький } & $\bar{X}$ & 2 & 2 & 1,2 & 0,8 \\
\hline & & $\sigma$ & 1 & 1 & 0,8 & 1,1 \\
\hline & & $\mathrm{t}$ & 4,$4 ; \mathrm{P}<0,05$ & 4,$5 ; \mathrm{P}<0,05$ & 3,$2 ; \mathrm{P}<0,05$ & 1,$7 ; \mathrm{P}>0,05$ \\
\hline \multirow[t]{3}{*}{$\mathrm{E} \Gamma$} & \multirow[t]{3}{*}{ Низький } & $\bar{X}$ & 1,2 & 0,6 & 1,4 & 0,8 \\
\hline & & $\sigma$ & 1,3 & 0,5 & 0,5 & 1,3 \\
\hline & & $\mathrm{t}$ & 2,$0 ; \mathrm{P}>0,05$ & 2,$4 ; \mathrm{P}<0,05$ & 5,$7 ; \mathrm{P}<0,05$ & 1,$4 ; \mathrm{P}>0,05$ \\
\hline \multicolumn{7}{|c|}{$t_{(0,05 ; 3)}=2,35$} \\
\hline
\end{tabular}

виявлення учбово-пізнавальної мотивації майбутніх бакалаврів з фізичної реабілітації, вчителів $з$ фізичної культури під час навчання (рис. 1).

Аналіз результатів анкети № 2 дослідження мотиваційного критерію готовності спрямованого на виявлення діяльнісної мотивації майбутніх фахівців з фізичної реабілітації, вчителів з фізичної культури під час навчання 32014 по 2017 навчальний рік у вищих навчальних закладах України (таблиця 2 та рис. 2) дав змогу виявити найбільший приріст середніх арифметичних різниць високого, середнього, достатнього та низького рівня оцінювання контрольних і експериментальних груп:

1. Після першого контрольного тестування (500 занять):

- у 2,5 разів в КГ найбільший приріст середніх арифметичних різниць на середньому рівні;
- у 2 рази в ЕГ найбільший приріст середніх арифметичних різниць на високому рівні;

- у 2 рази у ЕГ найбільший приріст середніх арифметичних різниць на достатньому рівні;

- у 2 рази в КГ найбільший приріст середніх арифметичних різниць на низькому рівні.

2. Після другого контрольного тестування (1000 занять):

- у 1,3 рази в КГ найбільший приріст середніх арифметичних різниць на середньому рівні;

- у 1,25 раз у ЕГ найбільший приріст середніх арифметичних різниць на середньому рівні.

3. Після третього контрольного тестування (1500 занять):

- у 1,25 разів в КГ найбільший приріст середніх арифметичних різниць на середньому рівні.

4. Після четвертого контрольного тестування (2000 занять): 


\section{СТАТИСТИЧНА ОБРОБКА ПОКАЗНИКІВ МОТИВАЦІЙНОГО ТА КОГНІТИВНОГО КРИТЕРІЮ \\ ГОТОВНОСТІ МАЙБУТНІХ БАКАЛАВРІВ 3 ФІЗИЧНОГО ВИХОВАННЯ І СПОРТУ ДО РЕАБІЛІТАЦЙНОЇ РОБОТИ З ДІТЬМИ З ОБМЕЖЕНИМИ ФІЗИЧНИМИ МОЖЛИВОСТЯМИ}

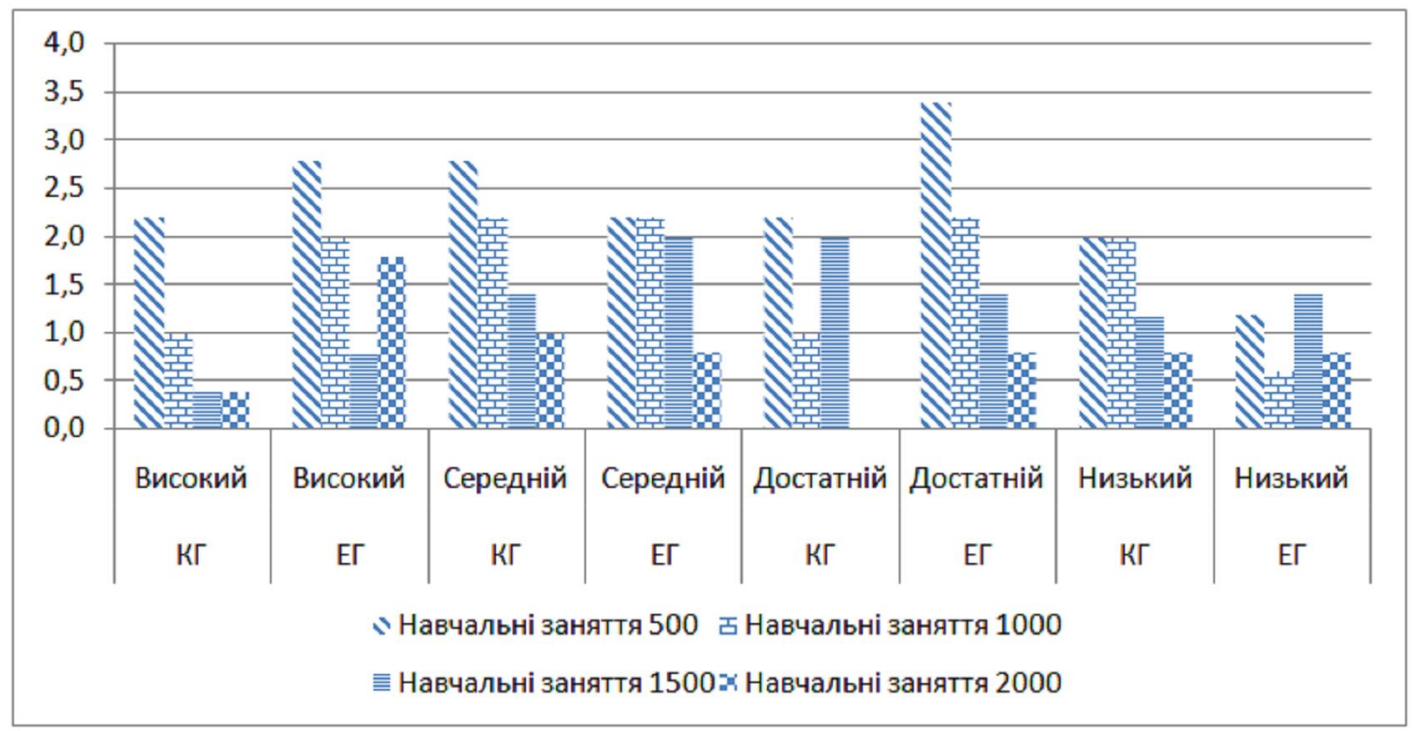

Рис. 3. Гістограма приросту показників когнітивного критерію готовності майбутніх бакалаврів 3 фізичної реабілітації, вчителів 3 фізичної культури під час навчання

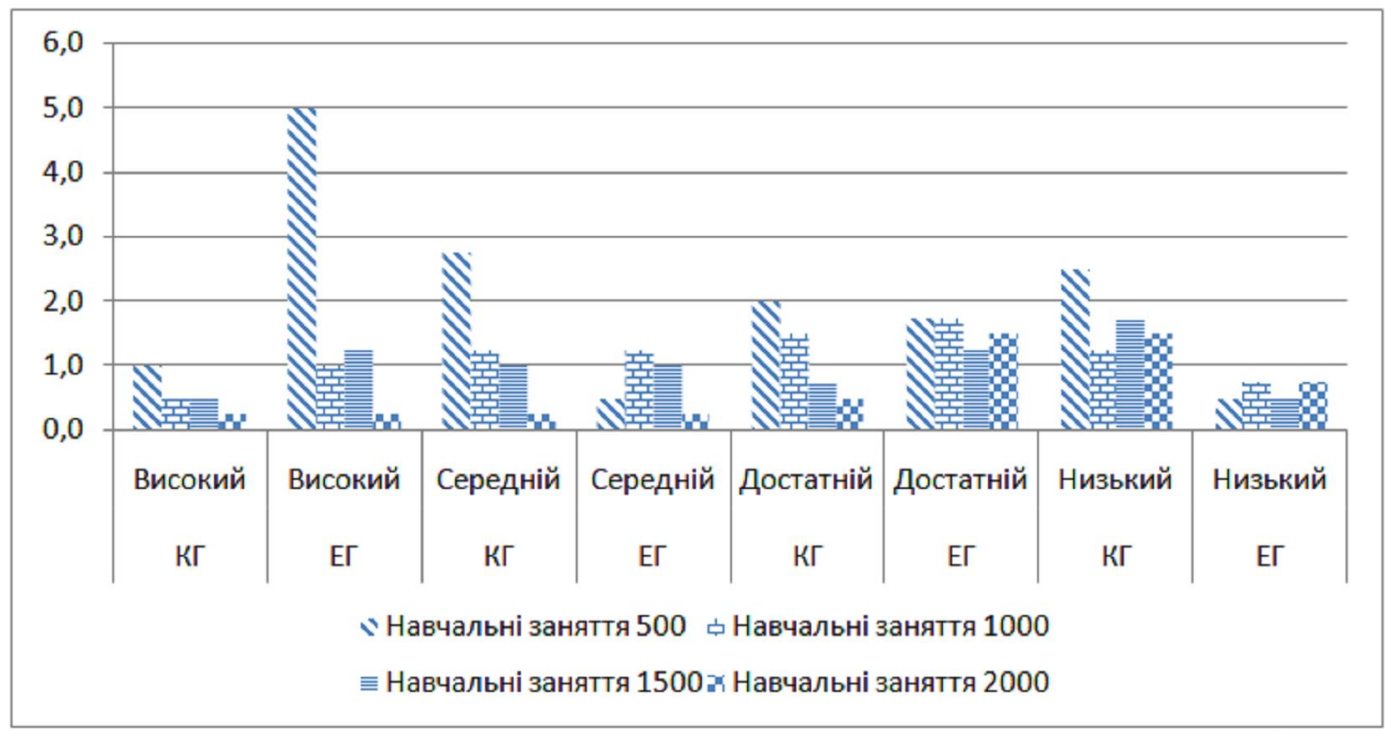

Рис. 4. Гістограма приросту показників когнітивного критерію готовності майбутніх бакалаврів 3 фізичної реабілітації, вчителів 3 фізичної культури під час навчання

- у 1,75 разів в КГ найбільший приріст середніх арифметичних різниць на низькому рівні;

- у 1,5 раз в ЕГ найбільший приріст середніх арифметичних різниць на високому рівні.

Аналіз результатів анкети № 3 дослідження когнітивного критерію готовності майбутніх фахівців з фізичної реабілітації, вчителів з фізичної культури під час навчання 32014 по 2017 навчальний рік у вищих навчальних закладах України (таблиця 3 та рис. 3) дав змогу виявити найбільший приріст середніх арифметичних різниць високого, середнього, достатнього та низького рівня оцінювання контрольних і експериментальних груп:

1.Післяпершогоконтрольного тестування (500 занять):
- у 2,8 разів в ЕГ найбільший приріст середніх арифметичних різниць на високому рівні;

- у 2,8 разів у КГ найбільший приріст середніх арифметичних різниць на середньому рівні;

- в 3,4 рази у ЕГ найбільший приріст середніх арифметичних різниць на достатньому рівні.

2.Після другогоконтрольноготестування (1000 занять):

- у 2,2 рази в КГ та ЕГ найбільший приріст середніх арифметичних різниць на середньому рівні;

- у 2,2 разів у КГ найбільший приріст середніх арифметичних різниць на достатньому рівні.

3. Після третього контрольного тестування (1500 занять):

- у 2 рази в ЕГ найбільший приріст середніх

Молодь і ринок №3 (158), 2018 


\section{СТАТИСТИЧНА ОБРОБКА ПОКАЗНИКІВ МОТИВАЩЙНОГО ТА КОГНІТИВНОГО КРИТЕРІЮ ГОТОВНОСТІ МАЙБУТНІХ БАКАЛАВРІВ 3 ФІЗИЧНОГО ВИХОВАННЯ І СПОРТУ ДО РЕАБІЛІТАЦІЙНОЇ РОБОТИ З ДІТЬМИ З ОБМЕЖЕНИМИ ФІЗИЧНИМИ МОЖЛИВОСТЯМИ}

Таблиця 4

Показники приросту когнітивного критерію готовності майбутніх бакалаврів 3 фізичної реабілітації, вчителів 3 фізичної культури під час навчання

\begin{tabular}{|c|c|c|c|c|c|c|}
\hline \multirow[t]{2}{*}{ Групи } & \multirow[t]{2}{*}{ Рівень } & \multirow{2}{*}{$\begin{array}{c}\text { Статистичні } \\
\text { показники }\end{array}$} & \multicolumn{4}{|c|}{ Навчальні заняття } \\
\hline & & & 500 & 1000 & 1500 & 2000 \\
\hline \multirow[t]{3}{*}{ КГ } & \multirow[t]{3}{*}{ Високий } & $\bar{X}$ & 1 & 0,5 & 0,5 & 0,25 \\
\hline & & $\sigma$ & 0,82 & 0,58 & 0,58 & 0,5 \\
\hline & & $\mathrm{t}$ & 2,$4 ; \mathrm{P}<0,05$ & 1,$7 ; \mathrm{P}<0,05$ & 1,$7 ; \mathrm{P}>0,05$ & $1 ; \mathrm{P}>0,05$ \\
\hline \multirow[t]{3}{*}{$\mathrm{E} \Gamma$} & \multirow[t]{3}{*}{ Високий } & $\bar{X}$ & 5 & 1 & 1,25 & 0,25 \\
\hline & & $\sigma$ & 1,8 & 0,82 & 0,5 & 0,96 \\
\hline & & $\mathrm{t}$ & 5,$4 ; \mathrm{P}<0,05$ & 2,$4 ; \mathrm{P}<0,05$ & $5 ; \mathrm{P}<0,05$ & 0,$52 ; \mathrm{P}<0,05$ \\
\hline \multirow[t]{3}{*}{ КГ } & \multirow[t]{3}{*}{ Середній } & $\overline{\mathrm{X}}$ & 2,75 & 1,25 & 1 & 1 \\
\hline & & $\sigma$ & 0,5 & 0,5 & 0,82 & 1,15 \\
\hline & & $\mathrm{t}$ & $11 ; \mathrm{P}<0,05$ & $5 ; \mathrm{P}<0,05$ & 2,$4 ; \mathrm{P}<0,05$ & 1,$7 ; \mathrm{P}<0,05$ \\
\hline \multirow[t]{3}{*}{$\mathrm{E} \Gamma$} & \multirow[t]{3}{*}{ Середній } & $\bar{X}$ & 0,5 & 1,25 & 1 & 0,25 \\
\hline & & $\sigma$ & 0,58 & 0,5 & 0,82 & 0,5 \\
\hline & & $\mathrm{t}$ & 1,$7 ; \mathrm{P}<0,05$ & $5 ; \mathrm{P}<0,05$ & 2,$4 ; \mathrm{P}<0,05$ & $1 ; \mathrm{P}>0,05$ \\
\hline \multirow[t]{3}{*}{ КГ } & \multirow[t]{3}{*}{ Достатній } & $\bar{X}$ & 2 & 1,5 & 0,75 & 0,5 \\
\hline & & $\sigma$ & 0,82 & 0,5 & 0,96 & 0,58 \\
\hline & & $\mathrm{t}$ & 4,$9 ; \mathrm{P}<0,05$ & 5,$2 ; \mathrm{P}<0,05$ & $3 ; \mathrm{P}<0,05$ & 1,$7 ; \mathrm{P}>0,05$ \\
\hline \multirow[t]{3}{*}{$\mathrm{E} \Gamma$} & \multirow[t]{3}{*}{ Достатній } & $\bar{X}$ & 1,75 & 1,75 & 1,25 & 1,5 \\
\hline & & $\sigma$ & 0,5 & 0,5 & 0,5 & 1,29 \\
\hline & & $\mathrm{t}$ & $7 ; \mathrm{P}<0,05$ & $7 ; \mathrm{P}<0,05$ & $5 ; \mathrm{P}<0,05$ & 2,$3 ; \mathrm{P}<0,05$ \\
\hline \multirow[t]{3}{*}{ КГ } & \multirow[t]{3}{*}{ Низький } & $\bar{X}$ & 2,5 & 1,25 & 1,75 & 1,5 \\
\hline & & $\sigma$ & 0,58 & 0,5 & 0,96 & 0,58 \\
\hline & & $\mathrm{t}$ & 8,$7 ; \mathrm{P}<0,05$ & $5 ; \mathrm{P}<0,05$ & 3,$6 ; \mathrm{P}<0,05$ & 5,$2 ; \mathrm{P}<0,05$ \\
\hline \multirow[t]{3}{*}{$\mathrm{E} \Gamma$} & \multirow[t]{3}{*}{ Низький } & $\bar{X}$ & 0,5 & 0,75 & 0,5 & 0,75 \\
\hline & & $\sigma$ & 0,58 & 0,5 & 0,58 & 0,5 \\
\hline & & $\mathrm{t}$ & 1,$7 ; \mathrm{P}>0,05$ & $3 ; \mathrm{P}<0,05$ & 1,$7 ; \mathrm{P}>0,05$ & $3 ; \mathrm{P}<0,05$ \\
\hline \multicolumn{7}{|c|}{$t_{(0,05 ; 3)}=2,35$} \\
\hline
\end{tabular}

арифметичних різниць на середньому рівні;

- у 2 рази в КГ найбільший приріст середніх арифметичних різниць на достатньому рівні.

4. Після четвертого контрольного тестування (2000 занять):

- у 1,8 раз в ЕГ найбільший приріст середніх арифметичних різниць на високому рівні.

Аналіз результатів анкети № 4 дослідження когнітивного критерію готовності майбугніх фахівців 3 фізичної реабілітації, вчителів з фізичної культури під час навчання з 2014 по 2017 навчальний рік у вищих навчальних закладах України (таблиця 4 та рис. 4) дав змогу виявити найбільший приріст середніх арифметичних різниць високого, середнього, достатнього та низького рівня оцінювання контрольних і експериментальних груп:

1. Після першого контрольного тестування (500 занять):
- у 5 раз в ЕГ найбільший приріст середніх арифметичних різниць на високому рівні.

2. Після другого контрольного тестування (1000 занять):

- у 1,5 разів в КГ та 1,75 в ЕГ найбільший приріст середніх арифметичних різниць на достатньому рівні.

3. Після третього контрольного тестування (1500 занять):

- у 1,75 раз в КГ найбільший приріст середніх арифметичних різниць на низькому рівні.

4. Після четвертого контрольного тестування (2000 занять):

- у 1,5 разів в ЕГ найбільший приріст середніх арифметичних різниць на достатньому рівні;

- у 1,5 разів в КГ найбільший приріст середніх арифметичних різниць на низькому рівні.

Висновки. Результати проведених досліджень 


\section{СТАТИСТИЧНА ОБРОБКА ПОКАЗНИКІВ МОТИВАЦИЙНОГО ТА КОГНІТИВНОГО КРИТЕРІЮ ГОТОВНОСТІ МАЙБУТНІХ БАКАЛАВРІВ 3 ФІЗИЧНОГО ВИХОВАННЯ І СПОРТУ ДО РЕАБІЛІТАЦЙННӦ̈ РОБОТИ З ДІТЬМИ $З$ ОБМЕЖЕНИМИ ФІЗИЧНИМИ МОЖЛИВОСТЯМИ}

експериментальної та загальної програм свідчать, що спостерігається достовірне покращення показників мотиваційного та когнітивного критерію готовності майбутніх фізичних реабілітологів у процесі застосування експериментальної програми. Тобто ефективність впливу запровадженої експериментальної програми в значній мірі обумовлена раціональною методикою та навчальним змістом запропонованої програми та робочого навчального плану упроцес підготовки майбутніх фахівців з фізичного виховання і спорту.

Проведені дослідження дають підставу стверджувати, що впровадження експериментальної "Програми підготовки фахівців 3 фізичного виховання і спорту до реабілітаційної роботи 3 дітьми з обмеженими фізичними можливостями" у навчальний процес майбутніх фахівців 3 фізичного виховання і спорту може суттєво впливати на рівень підготовки їх до фізичної реабілітації.

\section{ЛІТЕРАТУРА}

1. Башкін І. Роль і місце фізичної реабілітації у загальній системі охорони здоров'я населення / I. Башкін, Е. Макарова, А. Кавакзе Різік // Теорія i методика фізичного виховання і спорту. - 2006. - №3. - C. $25-29$.

2. Бєлікова Н. О. Теоретичні і методичні засади підготовки майбутніх фахівців з фізичної реабілітації до здоров'язбережувальної діяльності. - Дисертація д-ра пед. наук: 13.00.04, Кабінет Міністрів України, Нац. УН-т біоресурсів і природокористування України. - К., 2012. $-450 \mathrm{c}$.

3. Гайволя, Р. Ю. До питання професійної підготовки майбутніх фахівців фізичного виховання / Р. Ю. Гайволя // Молодіжний науковий вісник: Фізичне виховання і спорт: зб. наук. пр. / Волин. нац. ун-т ім. Лесі Українки. - Луцьк, 2007. - С. 3-7.

4. Демінська Л. О. Межпредметні зв'язки у процесі професійної підготовки майбутніх учителів фізичної культури: дис. ... канд. пед. наук: 13.00.04 / Демінська Лариса Олексіївна. - Донецьк, 2004. - 208 с.

5. Долинний Ю.О. Критерії успішності професійної готовності майбугнього фахівця з фізичного виховання до реабілітаційної роботи 3 дітьми 3 обмеженими фізичними можливостями / Ю.О.Долинний // Глухівські наукові читання - 2016. Актуальні питання суспільних та гуманітарних наук / Матеріали VI Міжнародної інтернет-конференції молодих учених і студентів 27 - 29 вересня 2016 року. - Глухів: РВВ Глухівського НПУ ім. О. Довженка. - 2016. - С. 54 58.

6. Долинний Ю.О. Сучасні теоретичні основи підготовки майбутніх фахівців з фізичного виховання і спорту до реабілітаційної роботи / Ю.О.Долинний // "Педагогика и современные аспекты физического воспитания”: зб. наук. праць II Міжнар. наук.-практ. конф., (21-22 квітня 2016 року) / за заг. ред. Ю. О. Долинного. - Краматорськ: ДДМА, 2016. - 374 с. - C. $235-241$.

7. Оржеховська В. М. Здоров'язбережувальне навчання івиховання:проблеми, пошук/В.М. Оржеховська / / Наукові записки НДУ ім. М. Гоголя: Психологопедагогічні науки. - 2011. - № 4. - С. 29-31.

8. Пєшкова О.В. Вступ до спеціальності (Фізична реабілітація): [навчальний посібник] / О.В. Пєшкова. - Харків, 2007. -147 с.

9. Попов С. Н. Физическая реабилитация / С. Н. Попов. - Ростов н/Д. : Феникс, 2006. -608 с.

10.Прихода І. В. Організаційно-методологічні підходи до професійної підготовки фахівців 3 фізичної реабілітації в Україні / І.В.Прихода // Проблеми сучасної педагогічної освіти. - 2007. - Вип. 15, Ч. 1. - С. $60-66$.

\section{REFERENCES}

1. Bashkin, I., Makarova, E. \& Kavakze Rizik, A. (2006). Rol i mistse fizychnoi reabilitatsii u zahalnii systemi okhorony zdorovia naselennia [A role and place of physical rehabilitation are in the general system of health protection population]. Teoriia $i$ metodyka fizychnoho vykhovannia i sportu, no. 3, pp. $25-29$. [in Ukrainian].

2. Bielikova, N. O. (2012). Teoretychni i metodychni zasady pidhotovky maibutnikh fakhivtsiv z fizychnoi reabilitatsii do zdoroviazberezhuvalnoi diialnosti [Theoretical and methodical principles of preparation of future specialists are on a physical rehabilitation to health activity]. Doctor's thesis. Cabinet of Ministers of Ukraine, National University of Bioresources and Natural Resources of Ukraine. Kyiv, 450 p. [in Ukrainian].

3. Haivolia, R. Yu. (2007). Do pytannia profesiinoi pidhotovky maibutnikh fakhivtsiv fizychnoho vykhovannia [To the question of professional preparation of future specialists of physical education]. The Youth Science Bulletin: Physical Education and Sport: A collection of scientific works Volynskiy Lesya Urrayinka National University. Lutsk, pp. 3-7. [in Ukrainian].

4. Deminska, L. O. (2004). Mezhpredmetni zviazky $u$ protsesi profesiinoi pidhotovky maibutnikh uchyteliv fizychnoi kultury [Limits subject of copula in the process of professional preparation of future teachers of physical culture]. Candidate's thesis. 208 p. [in Ukrainian].

5. Dolinnyj, Yr.A. (2016). Kriterii uspishnosti profesijnoyi gotovnosti majbutnogo faxivcya $\mathrm{Z}$ fizychnogo vyxovannya do reabilitacijnoyi roboty z ditmy z obmezhenymy fizichnymy mozhlyvostamy [Criteria of success of professional readiness of future specialist of physical education to rehabilitation work with children with limit physical possibilities]. Gluxivski naukovi chytannia. Aktualni pytannya suspilnyx ta gumanitarnyx nauk. Materialy VI Mizhnarodnoyi internet-konferenciyi molodyx uchenyx i studentiv 27 - 29 veresnya 2016 roku. - Hlukhiv scientific readings - 2016. Topical issues of the social sciences and the 


\section{МЕТОДИКА ФОРМУВАННЯ ПРОЕКТНО-АНАЛІТИЧНОЇ КОМПЕТЕНТНОСТІ МАЙБУТНІХ ОФІЦЕРІВ-ПРИКОРДОННИКІВ У ПРОЦЕСІ ФАХОВОЇ ПІДГОТОВКИ}

humanities. Procedings of the VI International Internet Conference of Young Scientists and Students, September 27 - 29th, 2016.(pp.54-58). Gluxiv: RVV Gluxivskogo NPU im. O. Dovzhenka. [in Ukrainian].

6. Dolinnyj, Yr.A. (2016). Suchasni teoretychni osnovy pidgotovky majbutnix faxivciv z fizychnogo vyxovannya i sportu do reabilitacijnoyi roboty [Modern theoretical bases of preparation of future specialists are on P.E and sport to rehabilitation work]. "Pedagogyka $i$ sovremtnnyi aspekty fizicheskogo vospitanya": $z b$. nauk. pracz II Mizhnar. nauk.-prakt. konf., (21-22 kvitnya 2016 roku). -"Pedagogy and modern aspects of physical education": A collection of scientific works II International Science-Practice Conference. (April 2122th, 2016). (pp. 235-241). Kramatorsk: DDMA. [in Ukrainian].

7. Orzhekhovska, V. M. (2011). Zdoroviazberezhuvalne navchannia $i$ vykhovannia [To health activity of studies and education]. Naukovi zapysky NDU im. M. Hoholia: Psykholoho-pedahohichni nauky, no. 4, pp. 29-31. [in Ukrainian].

8. Pieshkova, O.V. (2007). Vstup do spetsialnosti (Fizychna reabilitatsiia) [A prelude is of speciality (Physical rehabilitation)]. Kharkiv, 147p. [in Ukrainian].

9. Popov, S. N. (2006). Fizicheskaya reabilitatsiya [Physical rehabilitation]. Rostov n/D.: Feniks, 608p. [in Russian].

10. Prykhoda, I. V. (2007). Orhanizatsiinometodolohichni pidkhody do profesiinoi pidhotovky fakhivtsiv $z$ fizychnoi reabilitatsii $v$ Ukraini [Organizationally-methodological going near professional preparation of specialists on a physical rehabilitation in Ukraine]. Problemy suchasnoi pedahohichnoi osvity, vol. 15, part. 1, pp. $60-66$. [in Ukrainian].

Стаття надійшла до редакції 28.02.2018

УДК 355(477):004:378:377:14:001

DOI:

Юрій Мельничук, ад ’юнкт кафедри педагогіки та соціально-економічних дисциилін, факультет іноземних мов і гуманітарних дисциплін

Національна академія Державної прикордонної служби України імені Богдана Хмельницького

\section{МЕТОДИКА ФОРМУВАННЯ ПРОЕКТНО-АНАЛІТИЧНОЇ КОМПЕТЕНТНОСТІ МАЙБУТНІХ ОФІЦЕРІВ-ПРИКОРДОННИКІВ У ПРОЦЕСІ ФАХОВОЇ ПІДГОТОВКИ}

Стаття присвячена проблемі формування проектно-аналітичної компетентності майбутніх офіиеерів-прикордонників. Визначено зміст понять “проектно-аналітична компетентність”. Розкрито структуру “проектно-аналітичної компетентності майбутніх офіцерів-прикордонників”.

На основі аналізу структури проектно-аналітичноӥ компетентності майбутніх офіцерівприкордонників автор визначив методику ї̈ формування, яка є поетапною. Розкрито зміст кожного етапу щуодо формування проектно-аналітичної компетентності майбутніх офіцерів-прикордонників.

Ключові слова: проектно-аналітична компетентність, проектна культура, аналітична діяльність, майбутні офіцери-прикордонники, професійна підготовка, методика формування компетентності.

Лim. 13.

Yuriy Melnychuk, Adjunct of the Pedagogy and Socio-Economic Disciplines Department, Faculty of Foreign Languages and Humanities National Bohdan Khmelnytskiy Academy of the State Border Guard Service of Ukraine

\section{METHOD OF FORMATION OF PROJECT-ANALYTICAL COMPETENCE OF FUTURE OFFICERS-BORDERS IN THE PROCESS OF PROFESSIONAL PREPARATION}

The transition of Ukrainian higher education to the European model has caused the need to change the various aspects of the educational process. One of the main contradictions was the non-compliance with the requirements of the modern market system and the results of the professional training of graduates of higher educational institutions.

Modern society considers a specialist not only as a person who possesses knowledge, skills and skills of the professional sphere, but also is capable to effectively operate in the complex, sometimes non-standard situations, that is, competent. In these conditions, a growing competence becomes more and more competent, in particular, its implementation into the training of future border guards officers.

The article is devoted to the problem of the design and analytical competence of future officers-border guards. The content of the concepts "design and analytical competence" is determined. The structure of "design and analytical competence of future officers-border guards" is revealed.

On the basis of analysis of the structure of the design and analytical competence of future officersborder guards, the author determined the method of its formation, which is a phased process. The content of each stage is discussed in relation to the design and analytical competence of future officers-border guards.

Consequently, a thorough analysis of scientific literature made it possible to reveal the contents of the $P A C$ of the ILO, and, on the basis of it, to formulate methodological recommendations for its formation. 